\title{
Reduced defenses and increased herbivore preference of island chaparral shrubs compared to mainland relatives
}

\author{
Ryan A. Salladay $1,2,{ }^{*}$ and Aaron R. Ramirez ${ }^{1,3}$ \\ ${ }^{1}$ Department of Integrative Biology, University of California-Berkeley, Berkeley, CA 94720 \\ ${ }^{2}$ Ecology and Evolutionary Biology, University of California, Santa Cruz, Santa Cruz, CA 95060 \\ ${ }^{3}$ Department of Biology, Reed College, Portland, OR 97202
}

\begin{abstract}
The absence of herbivores from certain environments may select for plants that are less defended and more palatable compared to plants in similar environments that are exposed to herbivory. This potential loss of defenses becomes especially important when exotic herbivores are introduced to islands that historically lack such organisms, potentially resulting in negative effects on native island ecosystems. To test the hypothesis that island plants have reduced defensive traits, we measured structural defenses and palatability of 10 taxonomic pairs from contrasting island and mainland environments. Our study compares plants from Santa Catalina Island, California—which has a long history without large native herbivores followed by more recent human-caused introductions-to the adjacent southern California mainland where ungulate herbivores are native and common. Our results suggest that island plants have reduced structural defenses and are more preferred by herbivores compared to their mainland plant relatives. These patterns are likely driven by selection on plant traits in the unique and insular island environment. Reduced defenses and increased palatability of island plant species should be considered when developing management strategies for island ecosystems that historically lack native ungulate herbivores.
\end{abstract}

RESUMEN.-La ausencia de herbívoros en determinados ambientes puede propiciar la presencia de plantas más indefensas y apetecibles en comparación a las que encontramos en ambientes similares, pero expuestas a animales herbívoros. Esta posible disminución de las defensas cobra mayor importancia al introducir herbívoros exóticos en islas que históricamente carecían de dichos organismos, suscitando, a la larga, efectos negativos en los ecosistemas insulares nativos. Para probar la hipótesis de que las plantas de la isla poseen rasgos defensivos reducidos, medimos las defensas estructurales y la palatabilidad de 10 pares taxonómicos en ambientes contrastantes tanto de la isla como del continente. Nuestro estudio compara plantas de la isla de Santa Catalina, California (con un largo historial sin herbívoros nativos, pero con introducciones más recientes realizadas por el hombre), con las del continente vecino, al sur de California, donde los herbívoros ungulados nativos son habituales. Nuestros resultados sugieren que las plantas de las islas tienen defensas estructurales reducidas y son más preferidas por los herbívoros, en comparación con las del continente. Es probable que estos patrones estén impulsados por la selección de los rasgos de la planta en el singular entorno de la isla. Al desarrollar estrategias de manejo de los ecosistemas insulares, que históricamente carecen de herbívoros ungulados nativos, se deberá considerar la reducción de las defensas y el aumento de la palatabilidad de las especies vegetales de las islas.

Large mammalian herbivores have exerted an important selective force on plants in terrestrial ecosystems around the world. However, due to limitations in dispersal ability, large mammals are often absent from oceanic islands (Carlquist 1974, Whittaker 1998). It has been hypothesized that this characteristic of island environments has selected for a general reduction of antiherbivore defenses in island plants (Carlquist 1974). This hypothesis is based on a trade-off between growth and antiherbivore defense (Fine and Mesones
2004, Mooney et al. 2010, Züst and Agrawal 2017) which suggests that reducing investment in defenses allows for increased growth and competitive ability—a feature that would be advantageous for island plants with limited threat of attack by mammalian herbivores. Support for this hypothesis has been found in some island systems (Bowen and Van Vuren 1997, Vourc'h et al. 2001). However, not all island plants exhibit a lack of defenses (Givnish et al. 1994). Knowing which island plants lack defenses can clarify the potential

*Corresponding author: rsallada@ucsc.edu 
ecological impacts of exotic mammalian herbivores introduced to oceanic islands.

In the past couple of centuries, humans have been responsible for the introduction of large browsing and grazing mammals (e.g., goats, pigs, sheep, cattle, horses, donkeys, etc.) to island systems around the world (MatisooSmith 2009, Simberloff 2009). Such introductions have contributed to severe environmental degradation and extinction of endemic plant species on islands (Coblentz 1978, Minnich 1980, 1982, Vitousek 1988, Atkinson 1989, Simberloff 2009). It is generally assumed that the negative impacts of introduced herbivores are, in part, facilitated by reduced defenses in island plants. In general, plants that are naïve to herbivores are decimated by invasive species due to a lack of defenses (Desurmont et al. 2011). However, this assumption has rarely been tested.

Plants use structural and chemical defenses to protect themselves from herbivores (Mithöfer and Boland 2012, War et al. 2012). Common chemical defenses include low nutrient and moisture content, production of toxic metabolites, and compounds that reduce digestibility of plant tissues (Hay et al. 1994, Hartley and Jones 1997, Cronin et al. 2002). Two of the most common structural defenses are the presence of spines, thorns, or prickles (i.e., spinescence) and leaf mechanical strength (i.e., leaf toughness; Hanley et al. 2007). Spinescence has been shown to be effective at reducing herbivory rates (Milewski et al. 1991, Cash and Fulbright 2005) mainly by forcing vertebrate herbivores to be more careful when attempting to consume plant tissue and thus take smaller bites resulting in reduced biomass loss for the spinescent plant (Belovsky et al. 1991, Wilson and Kerley 2003). Furthermore, spinescence is more common in areas with an abundance of large browsing mammals (Myers and Bazely 1991, Grubb 1992) and when rates of herbivory are elevated (Young and Okello 1998, Young et al. 2003). Similarly, leaf toughness makes plant material less palatable and digestible (Grubb 1986, Robbins 1993), which can effectively deter vertebrate herbivores (Forsyth et al. 2005, Teaford et al. 2006).

Santa Catalina Island (SCI), located off the coast of southern California, has had a long history of isolation with no large native herbivores. SCI has never been connected to the mainland and has been continuously above water for at least the last 300,000 years (Schoenherr et al. 1999). SCI’s woody plant communities-which arrived via long-distance dispersal-colonized a novel environment devoid of the browsing and grazing pressure they likely experienced on the mainland. This long history of the absence of attack by large herbivores may have selected for plants that lack the antiherbivore defenses of their mainland relatives (Van Vuren and Bowen 1999).

In the 19th and 20th centuries, several large mammalian herbivores were introduced to SCI. These introductions included cattle (Bos taurus), sheep (Ovis aries), goats (Capra hircus), pigs (Sus scrofa), American bison (Bison bison), and mule deer (Odocoileus hemionus). Overgrazing by these introduced herbivores has extensively degraded the native plant communities by altering canopy structure and community composition (Minnich 1982, Schoenherr et al. 1999, Ramirez et al. 2012, Rick et al. 2014). Cattle operations largely ceased in the mid-1900s, sheep were removed in the 1920s, and goats and pigs were removed in 2002 and 2005, respectively (Catalina Island Conservancy Staff personal communication). While many of these herbivores have been removed from SCI, bison and mule deer remain and continue to apply browsing and grazing pressure on native plant communities (Ramirez et al. 2012, Rick et al. 2014).

The defensive traits and palatability of woody vegetation on SCI has never been assessed. Therefore the purpose of the present study was to address this knowledge gap by comparing antiherbivore defenses and palatability of plants in closely related taxonomic pairs from SCI and the adjacent mainland. Antiherbivore defenses were assessed by quantifying aspects of structural defense: spinescence and leaf toughness. Palatability of island plants was determined by conducting feeding preference trials. We hypothesized that island plants would exhibit reduced defenses and increased palatability compared to mainland relatives.

\section{Methods}

\section{Field Sites and Study Species}

Santa Catalina Island $\left(33^{\circ} 21^{\prime} \mathrm{N}, 118^{\circ} 21^{\prime} \mathrm{W}\right)$ is located approximately $40 \mathrm{~km}$ off the coast of southern California. The matched mainland 
TABLE 1. Summary of field site characteristics, showing similarities of the Santa Catalina sites and the matched mainland sites. Soil sampled at a depth of $0-10 \mathrm{~cm}$ was used to measure total N, total C, and particle size. Soil characteristics are means $(n=6)$ with standard error in parentheses. Climate data were collected from the Western Regional Climate Center (https://wrcc.dri.edu).

\begin{tabular}{lccccccc}
\hline Site & Aspect & $\begin{array}{c}\text { Elevation } \\
(\mathrm{m})\end{array}$ & $\begin{array}{c}\text { Total N } \\
(\%)\end{array}$ & $\begin{array}{c}\text { Total C } \\
(\%)\end{array}$ & $\begin{array}{c}\text { Sand/silt/ } \\
\text { clay }(\%)\end{array}$ & $\begin{array}{c}\text { Mean annual } \\
\text { temp. }\left({ }^{\circ} \mathrm{C}\right)\end{array}$ & $\begin{array}{c}\text { Mean annual } \\
\text { precip. }(\mathrm{cm})\end{array}$ \\
\hline Catalina Island & $\mathrm{NE}$ & 500 & $0.160(0.042)$ & $3.037(1.122)$ & $62 / 24 / 13$ & 15.9 & 29.6 \\
Santa Ana Mtns. & $\mathrm{NE}$ & 900 & $0.157(0.046)$ & $2.398(0.773)$ & $66 / 21 / 13$ & 17.8 & 28.9 \\
\hline
\end{tabular}

TABLE 2. Ten island-mainland species pairs used in this study. The Heteromeles, Cercocarpus, and Adenostoma pairs are conspecific, and the remaining pairs are congeneric. Four island species are endemic to the Channel Islands $(*)$, and one species is endemic to Santa Catalina Island $(* *)$.

\begin{tabular}{|c|c|c|}
\hline Genus & Island species & $\begin{array}{l}\text { Mainland } \\
\text { species }\end{array}$ \\
\hline Rhus & integrifolia & ovata \\
\hline Arctostaphylos & catalinae $^{* *}$ & glauca \\
\hline Quercus & pacifica* $^{*}$ & berberidifolia \\
\hline $\begin{array}{l}\text { Ceanothus } \\
\text { (Cerastes) }\end{array}$ & megacarpus insularis & crassifolius \\
\hline $\begin{array}{l}\text { Ceanothus } \\
\quad \text { (Ceanothus) }\end{array}$ & arboreus* & oliganthus \\
\hline Rhamnus & pirifolia* & ilicifolia \\
\hline Prunus & ilicifolia lyonii* & ilicifolia \\
\hline Heteromeles & arbutifolia & arbutifolia \\
\hline Cercocarpus & betuloides traskiae & betuloides \\
\hline Adenostoma & fasciculatum & fasciculatum \\
\hline
\end{tabular}

site is located in the Santa Ana Mountains near Lake Elsinore, California $\left(33^{\circ} 38^{\prime} \mathrm{N}\right.$, $\left.117^{\circ} 23^{\prime} \mathrm{W}\right)$. Both sites have similar geographic and topographic features, including latitude, slope, aspect, and elevation (Table 1). Similarities in soil characteristics were measured by soil particle size (percent sand, silt, and clay) and soil fertility (total carbon and total nitrogen) in the top $10 \mathrm{~cm}$ (Table 1). Soil characteristics were analyzed at UC Davis Analytical Labs using the combustion method for soil fertility (https://anlab.ucdavis.edu/analysis/Soils/ 320) and the hydrometer method for particle size (https://anlab.ucdavis.edu/analysis/Soils/ 470). Data managed by the Western Regional Climate Center (https://wrcc.dri.edu) were used to compare mean annual temperature and precipitation of the 2 sites (Table 1 ).

Both sites are dominated by chaparral shrub communities with similar plant species composition. Ten closely related island-mainland pairs were used in this study (Table 2). Of the 10 taxonomic pairs, 7 are congeneric and 3 are conspecific. The island-mainland pairs include 5 plant families that are dominant in southern California chaparral. Four of the island species are endemic to the Channel Islands (Prunus ilicifolia ssp. lyonii, Quercus pacifica, Ceanothus megacarpus var. insularis, and Ceanothus arboreus) and one species is endemic to Santa Catalina Island (Arctostaphylos catalinae).

\section{Morphological Defenses}

To quantify morphological defenses of leaves from island-mainland pairs, we measured leaf toughness (i.e., puncture strength) and leaf spinescence (number of spines/leaf area and total spine length/leaf area). Leaf toughness was quantified by measuring leaf puncture strength using a modified 600-g-range spring-scale penetrometer (Pesola, Switzerland) as described in Lowman and Box (1983). Leaves from 6 individuals per species were sampled in the field, bagged, and returned to the lab in an ice chest where they were measured within $24 \mathrm{~h}$. To measure puncture strength, each leaf was placed between 2 boards with a hole in the center which allowed the rod of the penetrometer to enter and rest on the leaf. The penetrometer was manually forced downward until the rod punctured the leaf. The mass $(\mathrm{g})$ required to puncture the leaf was recorded and used to calculate mean values for each of 9 islandmainland pairs (Arctostaphylos, CeanothusCeanothus, Ceanothus-Cerastes, Cercocarpus, Heteromeles, Prunus, Quercus, Rhamnus, and Rhus). The 10th species pair, Adenostoma, was not included because it has small needlelike leaves that could not be used for puncture strength measurements.

Only 3 of the genera studied (Heteromeles, Prunus, and Rhamnus) had spiny leaf margins. Therefore measurements of leaf spinescence were only performed for these 3 island-mainland pairs. Leaves from 6 individuals per species were measured. Leaf spinescence was quantified in 2 ways: (1) number of spines per leaf area and (2) total spine length 


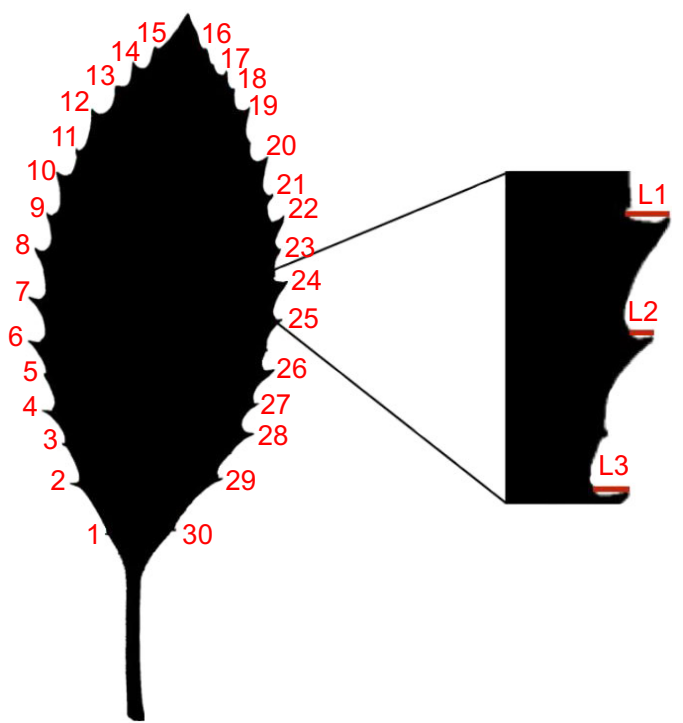

Fig. 1. Scanned leaf image illustrating methods for measuring leaf spinescence.

per leaf area (Bowen and Van Vuren 1997). Scanned images of leaves were analyzed using ImageJ 1.46 (U.S. National Institutes of Health, Bethesda, MD) to quantify spine number, spine length, and leaf area for each leaf (Fig. 1).

\section{Feeding Preference Trials}

Feeding trials with domesticated goats (Capra hircus) were used to compare mammalian herbivore preference of island-mainland pairs. Methods for feeding trials were modified from Bowen and Van Vuren (1997). In March 2013, three 50-cm-long branches from each of 6 individuals per species were harvested from island and mainland field sites. Branches were stored in an ice chest and immediately transported to the site of feeding trials (Goats R Us, Orinda, CA) where they were used within $72 \mathrm{~h}$ of harvesting. Ten trials were conducted over $2 \mathrm{~d}$-one trial per species pair. Prior to each trial the same 10 domesticated goats were left without food in a corral for $4 \mathrm{~h}$ to ensure sufficient hunger. In each trial 6 bouquets of harvested branches ( 3 island and 3 mainland) were attached to a feeding station and the goats were allowed to browse the bouquets for $10 \mathrm{~min}$. The bouquets were all placed at a uniform height $(75 \mathrm{~cm})$ and were arranged $60 \mathrm{~cm}$ apart in a random order. Each bouquet was weighed before and

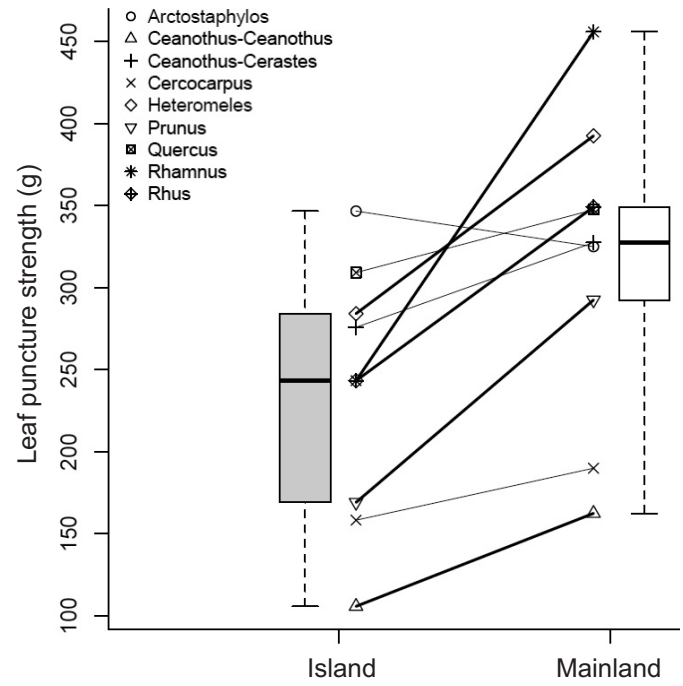

Fig. 2. Box plot of leaf toughness for 9 island-mainland pairs. Leaf toughness was estimated by leaf puncture strength (grams required to puncture a leaf). Island plants had significantly lower leaf toughness $\left(F_{1,98}=33.24, P<\right.$ 0.001). Boxes represent upper and lower quartiles, bars indicate ranges of values, and center lines show median values. Lines connect mean values for island-mainland pairs. Bold lines indicate significant differences for particular pairs $(P<0.05)$.

after feeding trials to determine the mass consumed by goats. The change in mass $(\mathrm{g})$ during feeding trials was used to calculate the percentage of initial biomass consumed by goats. Greater consumption of biomass in these feeding trials was attributed to greater preference of the foliage by goats.

\section{Statistical Analyses}

Differences in structural defenses and feeding preference between island-mainland pairs were analyzed using ANOVA with location (island/mainland) as a fixed effect and genus as a random effect. This model was used to test for a general difference between island-mainland congeners. If a significant difference was found in the ANOVA model, additional pairwise comparisons were used to test differences between individual pairs.

\section{Results}

\section{Morphological Defenses}

Leaf toughness, as estimated by leaf puncture strength, was lower in 8 out of 9 island plants (Fig. 2; $F_{1,98}=33.24, P<$ 

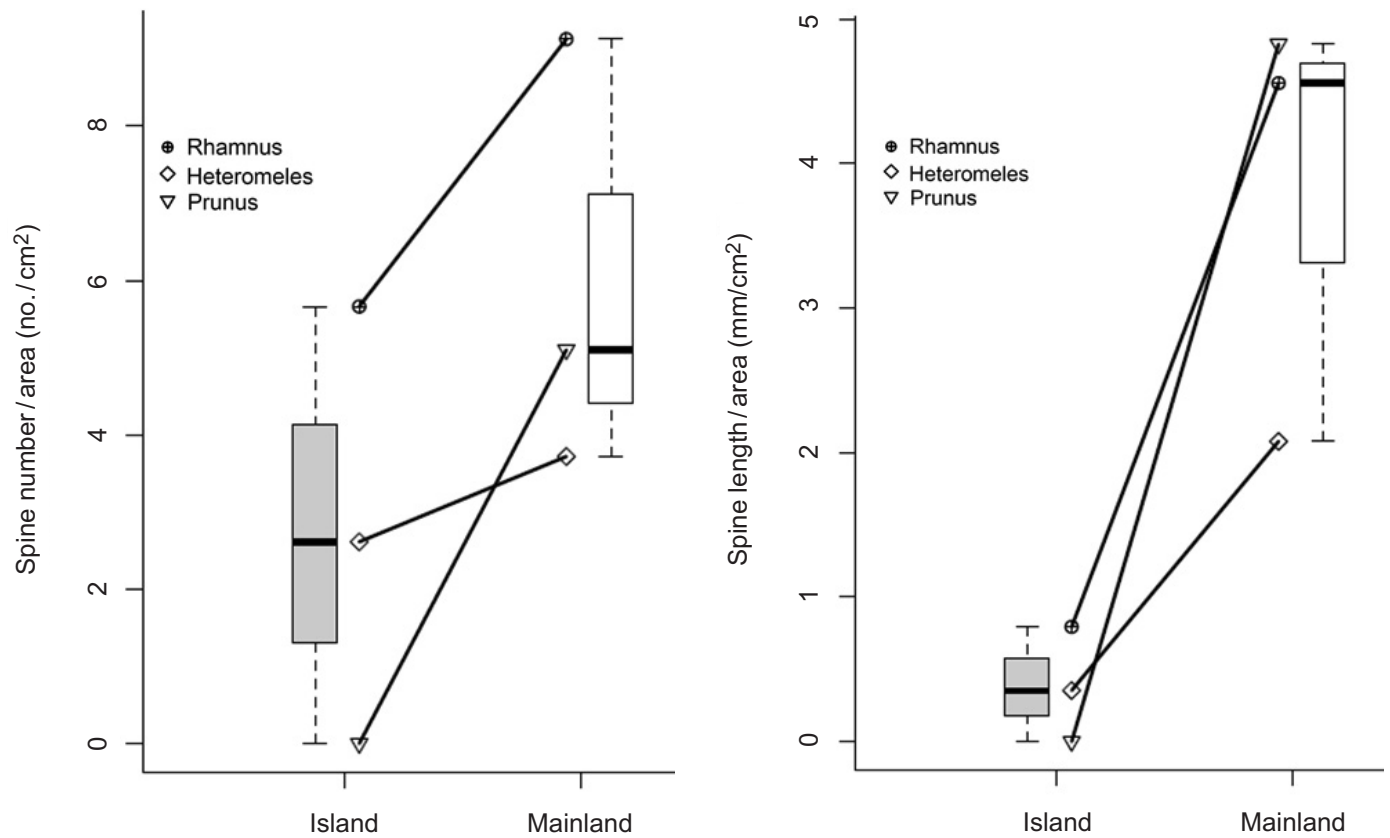

Fig. 3. Box plots of spine number per leaf area (left) and spine length per leaf area (right). Island plants had significantly fewer spines per leaf area $\left(F_{1,31}=60.4, P>0.001\right)$ and shorter spines per leaf area $\left(F_{1,31}=113.5, P<0.001\right)$. Boxes represent upper and lower quartiles, bars indicate ranges of values, and center lines show median values. Lines connect means of island-mainland pairs. All island-mainland pairs are significantly different for both traits $(P<0.05)$.
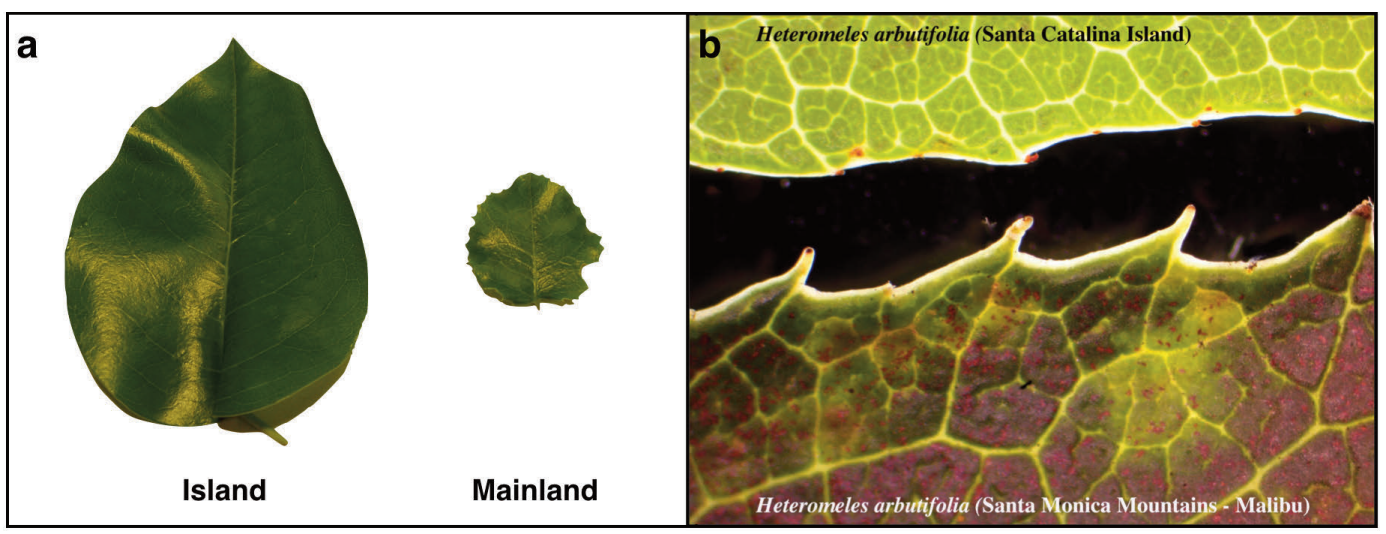

Fig. 4. Photographs illustrating differences in leaf traits between island-mainland pairs: a, differences in overall leaf size, shape, and spinescence between Prunus ilicifolia ssp. lyonii (island) and Prunus ilicifolia ssp. ilicifolia (mainland); b, Differences in marginal leaf spines of Heteromeles arbutifolia from island and mainland environments (photo by Stephen D. Davis).

0.001). Arctostaphylos was the only pair with higher leaf toughness on the island. The mean difference in puncture strength between island and mainland plants was $\sim 75$ g (Fig. 2). Island plants also had fewer spines per leaf area and shorter spines per leaf area (Fig. 3).
This pattern was consistent across all 3 islandmainland pairs. Differences in leaf spinescence were greatest for Prumus, which had virtually no leaf margin spines on the island (i.e., entire leaf margins) compared to the smaller and more spiny mainland leaves (Fig. 4a). 


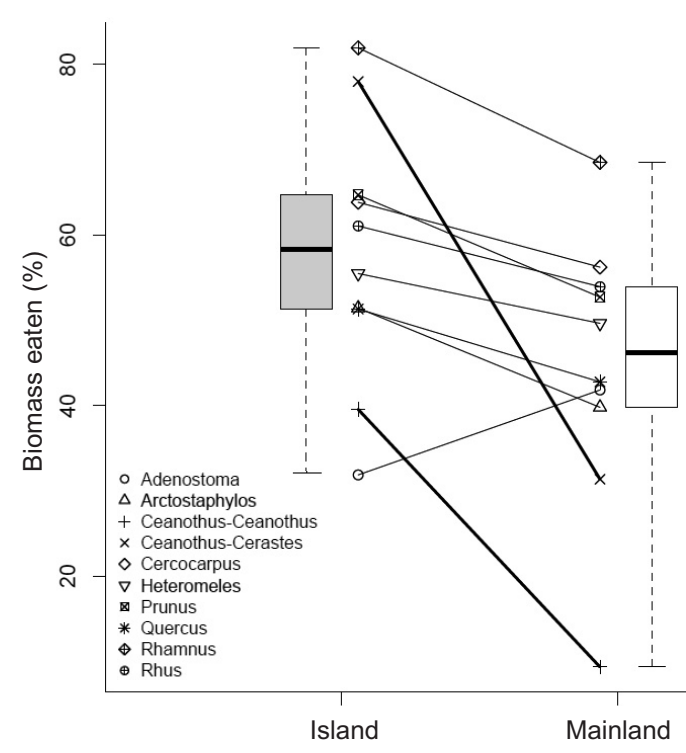

Fig. 5. Box plots of mean plant biomass eaten during feeding trials. Biomass eaten was calculated as a percentage of initial biomass offered. Island plants had significantly more biomass consumed by goats $\left(F_{1,49}=8.521, P=\right.$ 0.005). Boxes represent upper and lower quartiles, bars indicate ranges of values, and center lines show median values. Lines connect mean values of island-mainland pairs. Bold lines indicate significant differences for particular pairs $(P<0.05)$.

\section{Feeding Preference Trials}

Feeding preference was also consistently different between island-mainland pairs, with island plants being more preferred than their mainland relatives in 9 out of 10 pairs (Fig. 5; $\left.F_{1,49}=8.521, P=0.005\right)$. The only pair with a higher preference for the mainland taxon was Adenostoma. On average, goats consumed $15 \%$ more biomass from island plants (Fig. 5).

\section{Discussion}

Our results suggest that SCI plants have reduced structural defenses compared to mainland relatives. Island plants had significantly lower levels of both leaf toughness and leaf spinescence. Previous work has shown that tougher leaves are effective at deterring herbivores (Turner 1994), especially when more palatable options are available (Forsyth et al. 2005, Teaford et al. 2006), as was the case in our feeding preference trials. In addition, leaf margin spines of island plants were both shorter and less numerous, traits that have been associated with increased preference by sheep (Bowen and Van Vuren 1997). The most extreme example of differences in leaf spinescence came from Prunus; the leaves of $P$. ilicifolia ssp. lyonii from SCI had virtually no marginal spines compared to the smaller, tougher, and spinier leaves of its mainland relative (P. ilicifolia ssp. ilicifolia; Fig. 4a). Furthermore, there was likely a feedback effect of reduced leaf toughness on spinescence where leaf margin spines of island plants were not only shorter and less numerous but also more flimsy, potentially reducing their effectiveness as deterrents.

The less tough and less spiny leaves of island plants were also more preferred by goats during feeding trials. In 9 out of 10 feeding trials, island foliage was preferred over mainland offerings. The only trial in which this was not the case was with Adenostoma whose leaf toughness and spinescence were not measured due to the nature of its small needle-like leaves. Bowen and Van Vuren (1997) found similar preferences for island foliage in their study comparing vegetation from Santa Cruz Island-another of the California Channel Islands-during feeding trials with sheep. The presence of less defended and more palatable woody plants on SCI may lend support to the hypothesis that plants lose defenses in insular environments (Carlquist 1974).

It should be noted that the presence of introduced herbivores on SCI for the past century may have created a selective pressure for increased investment in herbivore defense by island plants. However, while herbivores have been present on SCI for over a century, many of the chaparral species in the present study may live much longer than that or, in the case of the shorter-lived obligate seeding taxa, only reproduce en masse when there is a fire. Fires are incredibly rare on the California Channel Islands (Carroll et al. 2009); therefore, the plants included in our study will have experienced very few generations and thus few opportunities for selection on increased defensive traits since the introduction of herbivores.

Consistent patterns of reduced defenses across multiple genera and families argue strongly for an environmental role in shaping these traits. However, many of the structural traits associated with antiherbivore defense 
may also serve other functions (Hanley et al. 2007). Leaf toughness (i.e., sclerophylly), for example, is frequently associated with gradients of nutrient and water availability (Wright et al. 2002, Ackerly 2004, Groom et al. 2004), with tougher leaves found in drier and more nutrient-poor environments. Similarly, spinescence has been linked to additional functions such as radiation flux (Nobel 1988) and climbing (Grubb 1992). The selection of leaf characteristics like leaf size and sclerophylly — which are also associated with antiherbivore defense (Turner 1994) — of SCI plants may be due, at least in part, to selection for more mesomorphic leaf types on islands (Hochberg 1980, Ramirez 2015). The idea that these structural leaf traits may have multiple functions that would be advantageous in insular environments may explain why differences exist between island and mainland congeners in leaf traits but not stem traits (Ramirez 2015). Future studies focusing on patterns of chemical defenses of SCI plants, which are less likely to be associated with factors other than antiherbivore defense, may strengthen the support of hypotheses concerning reduced defenses of SCI plants. Whatever the cause of less defended and more palatable vegetation on SCI, it is likely to have profound implications for the management of native plant communities and introduced herbivores.

The reduced defenses and greater palatability of island chaparral shrubs to herbivores should be considered when developing management strategies regarding introduced herbivore populations on SCI. In the past 2 centuries, introduced herbivores have drastically altered the ecological communities of SCI and the other California Channel Islands (Minnich 1980, 1982, Schoenherr et al. 1999, Ramirez et al. 2012, Rick et al. 2014). Any assumption that an introduced herbivore (e.g., mule deer) will have the same effect on SCI as on physiognomically similar mainland plant communities is not supported by the present study. The plant communities inhabiting SCI and the adjacent mainland have different evolutionary histories that have resulted in organisms with distinct ecologies and suites of traits. These unique histories and ecologies require management strategies that are specific to these environments.

\section{ACKNOWLEDGMENTS}

This research was supported by research grants from: the Gray Endowment, Integrative Biology Department, University of California, Berkeley; Grants-in-Aid of Research Program, Sigma Xi; and the Lawrence R. Heckard Endowment, UC Jepson Herbarium. Aaron Ramirez was supported by the National Science Foundation Graduate Research Fellowship. Ryan Salladay received funding from UC Berkeley's Environmental Sciences Research Seminar. The Catalina Island Conservancyespecially Jamie King, Peter Dixon, Ben Coleman, Linda Farley, and Sarah Ratayprovided access to the island and accommodations during field research trips. The Cleveland National Forest, Trabuco Ranger District, provided access to the Santa Ana Mountains field site. We would like to thank the Davis Lab at Pepperdine University, the Pratt Lab and Jacobsen Lab at CSU Bakersfield, and the Santiago Lab at UC Riverside for loaning field/lab equipment and lab space that was vital to the completion of this work. We also thank the many great field and lab assistants for their help: Jenn Mahley, Danica Witter, Jonathan Barber, Darko Cotoras, and Aditi Dubey.

\section{Literature Cited}

ACKerLy, D. 2004. Functional strategies of chaparral shrubs in relation to seasonal water deficit and disturbance. Ecological Monographs 74:25-44.

ATKINSON, I. 1989. Introduced animals and extinctions. In: D. Western and M.C. Pearl, editors, Conservation for the twenty-first century. Oxford University Press, New York, NY.

Belovsky, G.E., O.J. SchmitZ, J.B. Slade, and T.J. DawSON. 1991. Effects of spines and thorns on Australian arid zone herbivores of different body masses. Oecologia 88:521-528.

Bowen, L., AND D. VAN Vuren. 1997. Insular endemic plants lack defenses against herbivores. Conservation Biology 11:1249-1254.

Carlquist, S. 1974. Island biology. Columbia University Press, New York, NY.

Carroll, M.C., L.L. Laughrin, and A.C. Bromfield. 2009. Fire on the California islands: does it play a role in chaparral and closed cone pine forest habitats? Pages 73-88 in Third California Islands Symposium, Ventura, CA.

CASH, V.W., AND W.E. Fulbright. 2005. Nutrient enrichment, tannins, and thorns: effects on browsing of shrub seedlings. Journal of Wildlife Management 69:782-793.

Coblentz, B. 1978. The effects of feral goats (Capra hircus) on island ecosystems. Biological Conservation 13:279-286. 
Cronin, G., D.M. Lodge, M.E. Hay, M. Miller, A.M. Hill, T. Horvath, R.C. Bolser, N. Lindouist, and M. WAHL. 2002. Crayfish preferences for freshwater macrophytes: the influence of plant structure andzchemistry. Journal of Crustacean Biology 22: $708-718$

Desurmont, G.A., M.J. Donoghue, W.L. Clement, and A.A. AgRAWAL. 2011. Evolutionary history predicts plant defense against an invasive past. Proceedings of the National Academy of Sciences 108(17):7070-7074.

Fine, P., AND I. Mesones. 2004. Herbivores promote habitat specialization by trees in Amazonian forests. Science 305:663-665.

Forsyth, D.M., S.J. Richardson, and K. Menchenton. 2005. Foliar fibre predicts diet selection by invasive red deer Cervus elaphus scoticus in a temperate New Zealand forest. Functional Ecology 19:495-504.

Givnish, T.J., K.J. Sytsma, J.F. Smith, and W.J. Hahn. 1994. Thorn-like prickles and heterophylly in Cyanea: adaptations to extinct avian browsers on Hawaii? Proceedings of the National Academy of Sciences 91:2810-2814.

Groom, P.K., B.B. Lamont, S. Leighton, P. Leighton, AND C. BurRows. 2004. Heat damage in sclerophylls is influenced by their leaf properties and plant environment. Ecoscience 11:94-101.

GrubB, P.J. 1986. Sclerophyllys, pachyphylls and pycnophylls: the nature and significance of hard surfaces. Pages 137-150 in B. Juniper and T.R.E. Southwood, editors, Insects and the plant surface. Arnold, London.

GrubB, P.J. 1992. A positive distrust in simplicity-lessons from plant defences and from competition among plants and among animals. Journal of Ecology 80: $585-610$

Hanley, M.E., B.B. Lamont, M.M. Fairbanks, and C.M. RAFFERTy. 2007. Plant structural traits and their role in anti-herbivore defence. Perspectives in Plant Ecology, Evolution and Systematics 8(4):157-178. http://doi.org/10.1016/j.ppees.2007.01.001

Hartley, S.E., and C.G. JonEs. 1997. Plant chemistry and herbivory, or why is the World green? Pages 284-324 in M.J. Crawley, editor, Plant ecology. Blackwell, Oxford.

Hay, M.E., Q.E. Kappel, and W. Fenical. 1994. Synergisms in plant defences against herbivores: interactions of chemistry, calcification, and plant quality. Ecology 75:1714-1726.

Hochberg, M.C. 1980. Factors affecting leaf size of chaparral shrubs on the California islands. Pages 189-206 in D.M. Power, editor, The California islands: proceedings of a multidisciplinary symposium. Santa Barbara Museum of Natural History, Santa Barbara, CA.

Lowman, M.D., AND J.D. Box. 1983. Variation in leaf toughness and phenolic content among five species of Australian rain forest trees. Austral Ecology 8: $17-25$.

Matisoo-Smith, E. 2009. Pigs and goats. In: Encyclopedia of islands. University of California Press, Berkeley, CA.

Milewski, A.V., T.P. Young, And D. Madden. 1991. Thorns as induced defences: experimental evidence. Oecologia 86:70-75.

Minnich, R.A. 1980. Vegetation of Santa Cruz and Santa Catalina Islands. Pages 123-137 in D.M. Power, editor, The California islands: proceedings of a multi- disciplinary symposium. Santa Barbara Museum of Natural History, Santa Barbara, CA.

MinniCH, R.A. 1982. Grazing, fire and the management of vegetation on Santa Catalina Island, California. Pages 444-449 in C.E. Conrad and W.C. Oechel, editors, Proceedings of the symposium on dynamics and management of Mediterranean-type eco-systems. General Technical Report PSW-58, USDA Forest Service, Pacific Southwest Forest and Range Experiment Station.

Mithöfer, A., AND W. Boland. 2012. Plant defense against herbivores: chemical aspects. Annual Review of Plant Biology 63:431-450.

Mooney, K.A., R. Halitschie, A. Kessler, and A.A. AgraWAL. 2010. Evolutionary trade-offs in plants mediate the strength of trophic cascades. Science 327(5973):1642-1644.

Myers, J.H., AND D. BAZELY. 1991. Thorns, spines, prickles, and hairs: are they stimulated by herbivory and do they deter herbivores? Pages 325-344 in D.W. Tallamy and M.J. Raupp, editors, Phytochemical induction by herbivores. Wiley, New York, NY.

NobeL, P.S. 1988. Environmental biology of agaves and cacti. Cambridge University Press, Cambridge.

Ramirez, A., R. Pratt, and A. Jacobsen. 2012. Exotic deer diminish post-fire resilience of native shrub communities on Santa Catalina Island, southern California. Plant Ecology 213:1037-1047.

RamiREZ, A.R. 2015. Comparative ecophysiology and evolutionary biology of island and mainland chaparral communities. Doctoral dissertation, University of California, Berkeley, CA.

Rick, T.C., T.S. Sillett, C.K. Ghalambor, C.A. Hofman, K. Ralls, and R.S. Anderson. 2014. Ecological change on California's Channel Islands from the Pleistocene to the Anthropocene. BioScience 64(8): 680-692. https://doi.org/10.1093/biosci/biu094

Robbins, C.T. 1993. Wildlife feeding and nutrition. Academic Press, San Diego, CA.

Schoenherr A.A., C.R. Feldmeth, and M.J. Emerson. 1999. Natural history of the islands of California. University of California Press, Berkeley, CA.

SimberlofF, D. 2009. Introduced species. In: Encyclopedia of islands. University of California Press, Berkeley, CA.

Teaford, M.F., P.W. Lucas, P.S. Ungar, and K.E. GLander. 2006. Mechanical defences in leaves eaten by Costa Rican howling monkeys (Alouatta palliata). American Journal of Physical Anthropology 129:99-104.

Turner, I.M. 1994. Sclerophylly: primarily protective? Functional Ecology 8:669-675.

WhitTaKeR, R.J. 1998. Island biogeography: ecology, evolution, and conservation. Oxford University Press, New York, NY.

Wilson, S.L., AND G.I.H. Kerley. 2003. The effect of plant spinescence on the foraging ability of bushbuck and boergoats: browsers of a similar body size. Journal of Arid Environments 55:150-158.

VAN Vuren, D., AND L. Bowen. 1999. Reduced defenses in insular endemic plants: an evolutionary time frame. Conservation Biology 13:211-212.

Vitousek, P.M. 1988. Diversity and biological invasions of oceanic islands. Pages 181-189 in E.O. Wilson, editor, Biodiversity. National Academy Press, Washington, DC.

Vourc'H, G., J.L. Martin, P. Duncan, J. Escarre, and T.P. Clausen. 2001. Defensive adaptations of Thuja 
plicata to ungulate browsing: a comparative study between mainland and island populations. Oecologia 126:84-93.

War, A.R., M.G. Paulraj, T. Ahmad, A.A. Buhroo, B. Hussain, S. Ignacimuthu, and H.C. Sharma. 2012. Mechanisms of plant defense against insect herbivores. Plant Signaling and Behavior 7:1306-1320.

Wright, I.J., M. Westoby, And P.B. Reich. 2002. Convergence towards higher leaf mass per area in dry and nutrient-poor habitats has different consequences for leaf life span. Journal of Ecology 90:534-543.

Young, T.P., AND B.D. OKello. 1998. Relaxation of an induced defence after exclusion of herbivores: spines on Acacia drepanolobium. Oecologia 115:508-513.
Young, T.P., M.L. Stanton, and C.E. Christian. 2003. Effects of natural and simulated herbivory on spine lengths of Acacia drepanolobium in Kenya. Oikos 101:171-179.

Züst, T., AND A.A. Agrawal. 2017. Trade-offs between plant growth and defense against insect herbivory: an emerging mechanistic synthesis. Annual Review of Plant Biology 68:513-534.

Received 1 March 2017

Revised 26 September 2017

Accepted 13 November 2017 Published online 8 November 2018 